Piscopo, Jennifer M.; Siavelis, Peter M.: Chile's constitutional moment / Jennifer M. Piscopo, Peter M. Siavelis. - In: Current history (Philadelphia), 120 (2021) 823, S. 43-49, Lit.

Rocha, Camila: The new Brazilian right and the public sphere / Camila Rocha. - São Paulo: The Maria Sibylla Merian International Centre for Advanced Studies in the Humanities and Social Sciences Conviviality-Inequality in Latin America (Mecila), 2021 - [Elektronische Ressource (30S.)] (Mecila: working paper series; 32)

Sieder, Rachel: "To speak the law": contested jurisdictions, legal legibility, and sovereignty in Guatemala / Rachel Sieder. - In: Political and legal anthropology review (Oxford), 43 (2020) 2, S. 334-351, Lit. S. 347-351, Lit.Hinw. S. 346-347

\title{
NAHER UND MITTLERER OSTEN / NEAR AND MIDDLE EAST
}

Abdelmoula, Ezzeddine; Northey, Jessica Ayesha; Narriman Guemar, Latefa; Konarek, Katharina; Zeino-Mahmalat, Ellinor; Gençkaya, Ömer Faruk; Dikmen, Pinar: Reforms and elections in the Middle East and North Africa / Ezzeddine Abdelmoula, Jessica Ayesha Northey, Latefa Narriman Guemar, Katharina Konarek, Ellinor Zeino-Mahmalat, Ömer Faruk Gençkaya, Pinar Dikmen. - In: Orient (Berlin); 61 (2020) 2, S. 3-52

Abū-Rummān, Muḥammad: Democratic reform in Jordan? Expectations after the king's recent call to review political life / Muhammad Abū-Rummān. - Amman: FES Jordan \& Iraq, 2021 [Elektronische Ressource (22S.)] (Policy papers / Friedrich Ebert Stiftung)

Adar, Sinem; Seufert, Günter: Turkey's presidential system after two and a half years: an overview of institutions and politics / Sinem Adar, Günter Seufert. - [Elektronische Ressource (39S., Il1.)] (SWP research paper; 2021/2)

Ahmed, Imran; Brasted, Howard: Recognition and dissent: constitutional design and religious conflict in Pakistan / Imran Ahmed, Howard Brasted. - In: Journal of contemporary Asia (Abingdon), 51 (2021) 2, S. 351-367

Ahmed, Raja Qaiser; Tamoor, Maryum: State formation and the postcolonial decay in Pakistan / Raja Qaiser Ahmed, Maryum Tamoor. - In: Asian journal of social science (Leiden), 49 (2021) 1, S. 9-15

Bogaards, Matthijs: Iraq's constitution of 2005: the case against consociationalism 'light' / Matthijs Bogaards. - In: Ethnopolitics (London), 20 (2021) 2, S. 186-202, Tab., Lit. S. 198-202, Lit.Hinw. S. 196-197

Breyel, Corinna; Grigoriadis, Theocharis N.: Civil society, natural resources and dictatorship / Corinna Breyel, Theocharis N. Grigoriadis. - In: Eurasian geography and economics (Abingdon), 62 (2021) 2, S. 131-155, graph. Darst.

Cherif, Nedra: Libya's constitution: between conflict and compromise / Nedra Cherif. - San Domenico di Fiesole: European University Institute, 2021 - [Elektronische Ressource (24S.)] (RSCAS Middle East directions; 2) ISBN 978-92-9084-997-1 
Dagher, Ruby: Reconstructing our Understanding of State Legitimacy in Post-conflict States: building on Local Perspectives / Ruby Dagher. - Cham: Springer International Publishing, 2021 [Elektronische Ressource (XXII, 305S., Ill.)] (Rethinking Peace and Conflict Studies) ISBN 978-3-030-67254-6

Delatolla, Andrew: Civilization and the Making of the State in Lebanon and Syria / Andrew Delatolla. - Cham: Springer International Publishing, 2021 - IX, 285S., Ill. (Middle East Today) ISBN 978-3-030-57690-5

Frahm, Ole; Hoffmann, Katharina: Dual agent of transition: how Turkey perpetuates and challenges neo-patrimonial patterns in its post-Soviet neighbourhood / Ole Frahm, Katharina Hoffmann. - In: East European politics (Abingdon), 37 (2021) 1, S. 110-138

Gallo, Ernesto: Globalisation, authoritarianism and the post-Soviet state in Kazakhstan and Uzbekistan / Ernesto Gallo. - In: Europe Asia studies (Abingdon), 73 (2021) 2, S. 340-363

Gebrehiwot Berhe, Mulugeta; Detzner, Sarah: Sustaining momentum: seizing the opportunity for SSR in Sudan / Mulugeta Gebrehiwot Berhe, Sarah Detzner. - London: The London School of Economics and Political Science, 2020 - [Elektronische Ressource (31S.)]

Herzberg, Anne: Should Israel cooperate with the ICC? / Anne Herzberg. - Ramat Gan: The BeginSadat Center for Strategic Studies, 2020 - [Elektronische Ressource (15S.)] (Mideast security and policy studies; 190)

Hopkins, Benjamin D.: The war that destroyed America: Afghanistan's coming bill / Benjamin D. Hopkins. - In: Critical Asian studies (Abingdon), 53 (2021) 1, S. 147-159

Houdret, Annabelle: How can water sector cooperation support democratic governance? Insights from Morocco / Annabelle Houdret. - In: Middle East Law and Governance (Leiden), 13 (2021) 1, S. $72-97$

Hudákóva, Zuzana: Civil society in Tunisia: from islands of resistance to tides of political change / Zuzana Hudáková. - In: The journal of North African studies (London), 26 (2021) 3, S. 498-526, graph. Darst.

Jacobs, Andreas: Kein Frühling, ein Vorbote: zur Lesart der arabischen Umbrüche vor zehn Jahren / Andreas Jacobs. - In: Die politische Meinung (Osnabrück), 66 (2021) 566, S. 66-70

Khanani, Ahmed: All politics are God's politics: Moroccan Islamism and the sacralization of democracy / Ahmed Khanani. - New Brunswick: Rutgers University Press, 2021 - ix, 216S., Lit. S. 189-210 ISBN 978-1-978818-61-3; 978-1-978818-62-0

Lacher, Wolfram: Libya's flawed unity government: a semblance of compromise obscures old and new rifts / Wolfram Lacher. - Berlin: SWP, April 2021 - [Elektronische Ressource (8S.)] (SWP comment; 29)

Lavie, Limor; Shalaby, Abdallah: The civil state vs. the secular state in Arab discourse: Egypt as a case study / Limor Lavie, Abdallah Shalaby. - In: Strategic Assessment (Tel Aviv), 24 (2021) 1, S. $88-100$

Limam, Mohamed: Logiques autoritaires et transformation démocratique en Tunisie: le cas du président de l'Assemblée des Représentants du Peuple (2014-2019) / Mohamed Limam. - In: L' année du Maghreb (Paris), 22 (2020), S. 251-261 
Mogwe, Alice; Staberock, Gerald: Target locked: the unrelenting Israeli smear campaigns to discredit human rights groups in Israel, Palestine, and the Syrian Golan / Alice Mogwe, Gerald Staberock. Paris: FIDH, April 2021 - [Elektronische Ressource (63S., Ill.)]

Mohsen-Finan, Khadija: Tunisie, l'apprentissage de la démocratie / Khadija Mohsen-Finan. - Paris: Nouveau Monde éditions, 2021 - [Elektronische Ressource (239S.)] ISBN 978-2-38094-166-1

Riedel, Sabine: Looking back at 10 years of Arab Spring: as seen from theories on democracy, transformation, modernisation and interdependence / Sabine Riedel. - In: Forschungshorizonte Politik \& Kultur (Berlin), 5 (2021) 4, S. 1-14, Ill. Lit. S. 12-14

Rozențal, Ma oz; Barzilay, Gad; Meydani, Assaf: Judicial review in a defective democracy: judicial nominations and judicial review in constitutional courts / Ma' oz Rozențal, Gad Barzîlay, Assaf Meydani. - In: Journal of law and courts (Chicago), 9 (2021) 1, S. 137-157, Ill., Tab., Lit.Hinw.

Salt, Jeremy: The findings of the Hariri tribunal / Jeremy Salt. - In: Middle East policy (Oxford), 27 (2020) 4, S. 136-142, Lit.Hinw.

Schlumberger, Oliver: Puzzles of political change in the Middle East: political liberalisation, authoritarian resilience and the question of systemic change / Oliver Schlumberger. - Bonn: Deutsches Institut für Entwicklungspolitik gGmbH, 2021 - [Elektronische Ressource (117S.)] (Discussion paper / German Development Institute; 2021/5)

Situation in the Sudan and the activities of the United Nations Integrated Transition Assistance Mission in the Sudan: report of the Secretary-General / United Nations, Security Council. - New York: United Nations, March 2021 - [Elektronische Ressource (18S.)]

Skierkowski Hultquist, Agatha; Birnir, Jóhanna K.; Asal, Victor: The politics of co-optation: ethnopolitical minority organizations and authoritarian elections in the Middle East / Agatha Skierkowski Hultquist, Jóhanna K. Birnir, Victor Asal. - In: Ethnopolitics (London), 20 (2021) 2, S. 216-243, Tab., Lit. S. 232-235, Lit.Hinw. S. 230-232

Stacher, Joshua: Watermelon democracy: Egypt's turbulent transition / Joshua Stacher. - Syracuse: Syracuse University Presss, 2020 - xxiii, 257S., graph. Darst., Lit. S. 223-238 (Modern intellectual and political history of the Middle East) ISBN 978-0-8156-3677-9; 978-0-8156-3687-8

Van Schaack, Beth: Imagining justice for Syria / Beth Van Schaack. - New York: Oxford University Press, 2020 - xv, 476S., Ill. (Lieber Institute for Law and Land Warfare; 4) ISBN 978-0-19-005596-7

Wijler, Miryam: Ill-Gotten gains: theft of Palestinian land - declaring "state land" where settlement of title was halted when Israel occupied the West Bank / Miryam Wijler. - Tel Aviv: Yesh Din, February 2021 - [Elektronische Ressource (56S.)] (Position paper / Yesh Din)

Zahiri, Eva: Religion et pouvoir politique en Iran contemporain / Eva Zahiri. - In: Confluences Méditerranée (Paris), 113 (2020), S. 53-62 